\title{
ANALISIS PENDAPATAN DAN KELAYAKAN USAHA TANI JAGUNG DI DESA POOPO KECAMATAN PASSI TIMUR KABUPATEN BOLAANG MONGONDOW
}

\section{ANALYSIS OF INCOME AND FEASIBILITY OF CORN FARMING BUSINESS IN POOPO VILLAGE, EAST PASSI SUB-DISTRICT, BOLAANG MONGONDOW REGENCY}

\author{
$\underline{\text { Riko Rudolf Ratu }}^{(1)}$, Paulus Adrian Pangemanan ${ }^{(2)}$, Theodora Maulina Katiandagho ${ }^{(2)}$ \\ 1) Mahasiswa Program Studi Agribisnis, Fakultas Pertanian, Universitas Sam Ratulangi, Manado \\ 2) Dosen Program Studi Agribisnis, Fakultas Pertanian, Universitas Sam Ratulangi, Manado \\ *Penulis untuk korespondensi: rikorudolf27@gmail.com
}

Naskah diterima melalui Website Jurnal Ilmiah agrisosioekonomi@unsrat.ac.id

Kamis, 8 April 2021

Disetujui diterbitkan

Jumat, 28 Mei 2021

\begin{abstract}
This study aims to determine the amount of corn farming income and whether corn farming is feasible to be cultivated by corn farmers in Poopo Village, East Passi Sub-District, Bolaang Mongondow Regency. This research was conducted from December 2019 to February 2020. The data used in this research are primary data obtained through interviews with 30 (thirty) respondents of corn farmers. The analytical method used in this research is quantitative methods and is presented in tabular form which then analyzed using income analysis and $R / C$ ratio analysis. The results showed that the average income of corn farmers in Poopo Village, East Passi District was IDR 2,786,363.89 / farmer and IDR 2,604,078.40 / ha, with an $R / C$ value generated per farmer of 1.06. The value of $R$ / $C$ ratio produced is more than one, indicating that corn farming in Poopo Village, East Passi Sub-District, Bolaang Mongondow Regency is profitable and feasible to operate.
\end{abstract}

Keywords: income analysis; feasibility analysis; farming business; corn

\begin{abstract}
ABSTRAK
Penelitian ini bertujuan untuk untuk mengetahui besarnya pendapatan usahatani jagung dan apakah usahatani jagung tersebut layak diusahakan oleh petani jagung di Desa Poopo Kecamatan Passi Timur Kabupaten Bolaang Mongondow. Penelitian ini dilaksanakan pada bulan Desember 2019 sampai Februari 2020. Data yang digunakan dalam penelitian ini adalah data primer yang diperoleh melalui wawancara kepada 30 (tiga puluh) responden petani jagung. Metode analisis yang digunakan dalam penelitian menggunakan metode kuantitatif dan disajikan dalam bentuk tabel yang selanjutnya dianalisis menggunakan analisis pendapatan dan analisis $\mathrm{R} / \mathrm{C}$ rasio. Hasil penelitian menunjukkan bahwa besarnya pendapatan rata-rata petani jagung di Desa Poopo Kecamatan Passi Timur yaitu sebesar $\mathrm{Rp} 2.786,363,89 /$ petani dan $\mathrm{Rp} 2.604,078,40 /$ ha, dengan nilai $\mathrm{R} / \mathrm{C}$ yang dihasilkan per petani yaitu 1,06. Nilai R/C rasio yang dihasilkan lebih dari satu menunjukkan bahwa usahatani jagung di Desa Poopo Kecamatan Passi Timur Kabupaten Bolaang Mongondow menguntungkan dan layak diusahakan.
\end{abstract}

Kata Kunci: analisis pendapatan; analisis kelayakan; usahatani; jagung 


\section{PENDAHULUAN}

\section{Latar Belakang}

Salah satu sektor yang dapat diandalkan untuk menunjang laju pertumbuhan ekonomi nasional adalah sektor pertanian, karena sektor pertanian merupakan salah satu basis yang diharapkan dalam menunjang pertumbuhan ekonomi yang baik pada saat ini maupun masa akan datang (Soekartawi, 2002). Sektor pertanian terdiri dari sub sektor tanaman pangan yang meliputi padi, palawija dan hortikultura, serta sub sektor tanaman perkebunan. Hortikultura merupakan salah satu bagian dari sektor pertanian yang dapat dijadikan sumber pertumbuhan ekonomi di Indonesia. Salah satu tanaman holtikultura yang banyak diusahakan oleh sebagian besar masyarakat Indonesia adalah tanaman jagung. Komoditas jagung tergolong komoditas yang strategis karena memenuhi kriteria antara lain memiliki pengaruh terhadap harga komoditas pangan lainnya, memiliki prospek yang cerah, memiliki kaitan ke depan dan ke belakang yang cukup baik. Bahkan di beberapa tempat, jagung merupakan bahan makanan pokok utama pengganti beras atau sebagai campuran beras.

Prospek usahatani tanaman jagung cukup cerah apabila dikelola secara intensif dan komersial berpola agribisnis. Permintaan pasar dalam negeri dan peluang ekspor komoditas jagung cenderung meningkat dari tahun ke tahun, baik dalam kebutuhan pangan maupun non pangan (Rukmana, 2008). Berdasarkan hal tersebut, maka penulis tertarik untuk melakukan penelitian terhadap petani jagung di desa Poopo untuk menganalisis pendapatan dan tingkat kelayakan usahatani jagung.

\section{Jagung}

Tanaman jagung termasuk dalam keluarga rumput-rumputan dengan spesies Zea mays L. Jagung (Zea mays L.) merupakan salah satu komoditas tanaman pangan musiman yang sudah diusahakan oleh masyarakat petani secara turun temurun. Jagung salah satu bahan pangan penting karena merupakan sumber karbohidrat penting kedua setelah beras di Indonesia. Penggunaan jagung sebagai bahan pangan dan pakan terus mengalami peningkatan. Sementara ketersediaannya dalam bentuk bahan terbatas, untuk itu perlu dilakukan upaya peningkatan produksi melalui perluasan lahan penanaman dan peningkatan produktivitas. Potensi pemasaran jagung terus mengalami peningkatan (Mukhlis, 2007).

\section{Pengertian Usahatani}

Menurut Soekartawi (2002), usahatani biasa diartikan sebagai ilmu yang mempelajari bagaimana seseorang mengalokasikan sumberdaya yang ada secara efektif dan efisian untuk tujuan memperoleh keuntungan yang tinggi pada waktu tertentu. Efektif dimaksudkan bila petani atau produsen dapat mengalokasikan sumberdaya yang mereka miliki (yang dikuasai) sebaik-baiknya, sedangkan dikatakan efesien bila pemanfaatan sumberdaya tersebut menghasilkan keluaran yang melebihi masukan. efisien usaha tani dapat diukur dengan cara menghitung efisiensi teknis dan harga serta ekonomis. Ketiga macam efisiensi ini penting untuk diketahui dan diraih oleh petani bila ia menginginkan keuntungan yang sebesarbesarnya.

Usahatani dapat berupa usaha bercocok tanam atau memelihara ternak. Dalam ekonomi pertanian dibedakan pengertian produktivitas dan pengertian produktivitas ekonomis dari pada usahatani. Dalam pengertian ekonomis maka letak atau jarak usahatani dari pasar penting sekali artinya. Kalau dua buah usahatani yang lebih dekat dengan pasar penting sekali artinya. Kalau dua buah usahatani mempunyai produktivitas fisik yang sama, maka usahatani lebih dekat dengan pasar mempunyai nilai lebih tinggi karena produktivitas ekonominya lebih besar (Astuti, 2013). Terdapat 4 (empat) unsur essensial dalam kegiatan usahatani yang perlu diperhatikan, yaitu:

1. Tanah, sebagai lapisan tipis penutup permukaan bumi, serta menjamin pertumbuhan tanaman, hewan, dan manusia. Terdapat empat komponen utama yang mendukung kemungkinan hidupnya tumbuhan, yaitu bahan mineral, bahan organik, air dan udara.

2. Modal, yaitu barang atau uang yang bersama-sama faktor produksi tanah dan 
tenaga kerja menghasilkan output (hasil pertanian).

3. Sumber Daya Manusia, yaitu faktor produksi berupa tenaga kerja.

4. Manajemen Pertanian, yaitu pengelolaan atau ketatalaksanaan pertanian yang sebaikbaiknya secara terencana, terorganisasi atau terkontrol dalam batasan fungsi produksi yaitu mengatur faktor-faktor alam, tenaga kerja dan modal dengan tujuan mencapai keberhasilan usahatani yang digarap.

\section{Biaya Usahatani}

Nilai dari barang dan jasa yang digunakan dalam usahatani untuk memproduksi komoditi yang diusahakan didefinisikan sebagai biaya usahatani. Biaya adalah pengorbanan sumber ekonomi yang diukur dalam satuan uang yang telah terjadi atau kemungkinan akan terjadi untuk tujuan tertentu. Selanjutnya biaya usahatani diklasifikasikan menjadi dua, yaitu:

1. Biaya tetap, umumnya didefinisikan sebagai biaya yang relatif tetap jumlahnya dan terus dikeluarkan walaupun produksi yang diperoleh banyak atau sedikit, jadi besarnya biaya tetap ini tidak tergantung pada besar kecilnya produksi yang diperoleh.

2. Biaya tidak tetap, biasanya didefinisikan sebagai biaya yang besar kecilnya dipengaruhi oleh produksi yang diperoleh, contoh: biaya untuk sarana produksi, biaya tenaga kerja dan sebagainya.

Dengan demikian total biaya merupakan jumlah dari biaya tetap dan biaya tidak tetap (variable), yang dirumuskan sebagai berikut:

Keterangan:

$$
\mathbf{T C}=\mathbf{T F C}+\mathbf{T V C}
$$

$\mathrm{TC}=$ Total Cost (Total Biaya)

TFC = Total Fix Cost (Total Biaya Tetap)

TVC $=$ Total Variable Cost $($ Total Biaya Variabel)

\section{Penerimaan Usahatani}

Penerimaan usahatani adalah perkalian antara produksi yang diperoleh dengan harga jual. Penerimaan usahatani dapat dibedakan menjadi dua, yaitu penerimaan bersih usahatani dan penerimaan kotor usahatani. Penerimaan bersih usahatani adalah merupakan selisih antara penerimaan kotor usahatani dengan penerimaan total usahatani. Pengeluaran total usahatani adalah nilai semua masukan yang habis terpakai dalam proses produksi, tidak termasuk tenaga kerja dalam keluarga petani. Sedangkan penerimaan kotor usahatani adalah nilai total produksi usahatani dalam jangka waktu tertentu baik yang dijual maupun tidak dijual (Shinta, 2005).

Penerimaan usahatani yaitu penerimaan dari sumber-sumber usahatani meliputi nilai jual hasil, penambahan jumlah inventaris, nilai produk yang dikonsumsi petani dan keluarganya. Penerimaan usahatani didapat melalui perkalian antara produksi yang diperoleh dengan harga jualnya. Besarnya pendapatan petani dan usahatani dapat menggambarkan kemajuan ekonomi usahatani dan besarnya tingkat pendapatan ini juga digunakan untuk membandingkan keberhasilan petani yang satu dengan petani yang lainnya.

Keterangan:

$$
\mathbf{T R}_{\mathbf{i}}=\mathbf{Y}_{\mathbf{i}} \times \mathbf{P}_{\mathbf{i}}
$$

$\mathrm{TR}_{\mathrm{i}}=$ Total Revenue (Penerimaan Usahatani) $\mathrm{Y}_{\mathrm{i}}=$ Output (Produksi dalam suatu Usahatani) $\mathrm{Py}_{\mathrm{i}}=$ Price (Harga Produk)

Analisis pendapatan usahatani memerlukan dua hitungan pokok, yaitu keadaan penerimaan dan keadaan pengeluaran selama jangka waktu yang ditetapkan. Penerimaan usahatani berwujud tiga hal, yaitu:

1. Hasil penjualan tanaman, ternak, dan hasil ternak

2. Produksi yang dikonsumsikan keluarga

3. Kenaikan nilai industri

\section{Pengertian Pendapatan}

Pendapatan adalah penerimaan bersih seseorang baik berupa uang kontan atau naturan. Menurut Shinta (2005) pendapatan dalam pengertian ilmu ekonomi adalah hasil berupa uang atau material lainnya, yang dicapai dari penggunaan kekayaan atau jasajasa manusia bebas, pendapatan sebagai jumlah penghasilan yang diperoleh dari jasajasa produksi yang diserahkan pada suatu jumlah uang yang diterima oleh masyarakat 
rumah tangga, yang boleh dibelanjakan oleh penerima untuk barang dan jasa sesuai dengan keinginannya. Pendapatan perusahaan berasal dari penjualan sementara itu, nilai penjualan ditentukan oleh jumlah unit terjual dan harga jual, atau lebih sederhana dikatakan pendapatan fungsi (Noor, 2007).

\section{Konsep Kelayakan Usahatani}

Kelayakan usahatani dihitung berdasarkan analisis pendapatan yang berasal dari kegiatan operasi keuangan. Hasil kegiatan operasi keuangan di ukur dari selisih antara penjualan yang diperoleh dengan biaya yang dikeluarkan. Pendapatan yang besar tidak selalu menunjukkan efisiensi yang tinggi dari usahatani, kerena kemungkinan pendapatan yang besar itu diperoleh dari investasi yang berlebihan. Oleh sebab itu analisis pendapatan akan lebih baik apabila diikuti dengan pengukuran kelayakan usahatani tersebut melalui analisis R/C Ratio, yang merupakan perbandingan antara penerimaan dan biaya produksi, dimana makin tinggi nilai $\mathrm{R} / \mathrm{C}$ Ratio makin baik nilai usahatani tersebut.

\section{Rumusan Masalah}

Berdasarkan uraian diatas maka yang menjadi rumusan masalah pada penelitian ini yaitu bagaimana pendapatan dan kelayakan usaha tani jagung di Desa Poopo Kecamatan Passi Timur Kabaputen Bolaang Mongondow.

\section{Tujuan Penelitian}

Tujuan penelitian ini yaitu untuk mengetahui besarnya pendapatan usahatani jagung dan apakah usahatani jagung tersebut layak diusahakan oleh petani jagung di Desa Poopo Kecamatan Passi Timur Kabupaten Bolaang Mongondow.

\section{Manfaat Penelitian}

Manfaat dari penelitian ini adalah:

1. Sebagai bahan informasi bagi petani jagung dalam mengelola dan mengembangkan usahataninya.

2. Hasil Penelitian diharapkan dapat digunakan oleh pemerintah daerah setempat sebagai bahan masukan dalam membuat kebijakan.

\section{METODE PENELITIAN}

\section{Waktu dan Tempat Penelitian}

Penelitian ini berlangsung selama 3 bulan yaitu dari bulan Desember 2019 sampai Februari 2020 mulai dari persiapan sampai pada penyusunan laporan. Penelitian ini dilakukan di Desa Poopo Kecamatan Passi Timur Kabupaten Bolaang Mongondow.

\section{Metode Pengumpulan Data}

Pengumpulan data menggunakan pendekatan secara individual melalui kegiatan observasi langsung ke lapangan untuk mengidentifikasi petani yang mengusahatani Jagung. Pengambilan data dilakukan dengan dua jenis data, yaitu data primer dan data sekunder. Data primer diperoleh dari hasil wawancara langsung dengan responden serta menggunakan daftar kuesioner. Sedangkan untuk data sekunder diperoleh dari literaturliteratur yang terkait dengan penelitian ini.

\section{Metode Pengambilan Sampel}

Metode pengambilan sampel dalam penelitian ini dilakukan dengan metode sampel acak sederhana (simple random sampling). Dalam hal ini yang menjadi responden yaitu Petani Jagung yang berada di Desa Poopo Kecamatan Passi Timur Kabupaten Bolaang Mongondow dengan jumlah responden sebanyak 30 petani.

\section{Metode Analisis Data}

Untuk menganalisis data dalam penulisan skripsi ini, penulis mengunakan dalam metode analisis kuantitatif yaitu data yang di peroleh dari penelitian dalam bentuk angka yang disusun dengan tabelaris selanjutnya akan dibahas dan dianalisisdengan model persamaan-persamaan yang telah ditentukan (Soekartiwi, 1996). Jadi pendapatan usahatani jagung dapat dirumuskan sebagai berikut:

$$
\pi=\mathbf{T R}-\mathbf{T C}
$$

keterangan:

$\pi=$ Pendapatan Usahatani

$\mathrm{TR}=$ Total Penerimaan

$\mathrm{TC}=$ Total Biaya 
Untuk mengetahui kelayakan usahatani, maka digunakan rumus Analisis Return Cost Ratio.

$$
\mathbf{a}=\mathbf{R}: \mathbf{C}
$$

keterangan:

$$
\begin{aligned}
& \mathrm{a}=\text { Return Cost Ratio } \\
& \mathrm{R}=\text { Return (Penerimaan) } \\
& \mathrm{C}=\text { Cost (Biaya) }
\end{aligned}
$$

Apabila :

$\mathrm{R} / \mathrm{C}=1$, Usahatani tidak menguntungkan dan tidak rugi

$\mathrm{R} / \mathrm{C}<1$, Usahatani tidak layak, Usahatani Rugi

$\mathrm{R} / \mathrm{C}>1$, Usahatani layak, Usahatani Untung

\section{HASIL DAN PEMBAHASAN}

\section{Deskripsi Wilayah Penelitian}

Desa Poopo merupakan salah satu desa yang terletak di Kecamatan Passi Timur, Kabupaten Bolaang Mongondow. Desa Poopo berada $\pm 70 \mathrm{~km}$ dari ibu kota Kabupaten Bolaang Mongondow di Lolak sebelah timur, $3 \mathrm{~km}$ dari ibu kota Kecamatan Passi Timur. Desa Poopo memiliki luas wilayah $560 \mathrm{Ha}$. Adapun batas administratif Desa Poopo sebagai berikut:

a. Sebelah utara berbatasan dengan perkebunan Desa Poopo.

b. Sebelah barat berbatasan dengan Desa Pangian.

c. Sebelah selatan berbatasan dengan Desa Poopo.

d. Sebelah timur berbatasan Hutan Lindung.

\section{Karakteristik Sampel Petani Jagung}

\section{Umur}

Cara atau pola fikir dan kemampuan fisik seseorang untuk bekerja biasanya dikaitkan dengan tingkat umur seseorang. Seseorang yang bekerja pada sektor pertanian amat mengandalkan kemampuan fisik, sehingga fisik yang prima sangat diperlukan. Hal ini penting karena mempengaruhi produktivitas kerja petani. Umur juga berpengaruh kepada kemampuan logika petani dalam rangka pengambilan keputusan yang tepat untuk

\begin{tabular}{|c|c|c|c|}
\hline \multirow[b]{2}{*}{ No } & \multirow[b]{2}{*}{$\begin{array}{l}\text { Golongan umur } \\
\text { (tahun) }\end{array}$} & \multicolumn{2}{|c|}{ Petani } \\
\hline & & Jumlah & $\begin{array}{c}\text { Persentase } \\
(\%)\end{array}$ \\
\hline 1. & $\leq 49$ & 14 & 46,67 \\
\hline 2. & $50-59$ & 6 & 20 \\
\hline 3. & $\geq 60$ & 10 & 33,33 \\
\hline & Total & 30 & 100 \\
\hline
\end{tabular}
mengalokasikan saprodi yang dibutuhkan dan juga dapat mempengaruhi kemampuan manajerial petani.

Sumber : Diolah dari data primer, 2020

Tabel 1 menunjukkan bahwa sebagian besar petani jagung berada pada kelompok umur dibawah 50 tahun, dengan jumlah petani sebanyak 14 orang atau 46,67\%. Diikuti pada kelompok umur $\geq 60$ tahun yaitu masingmasing sebanyak 10 orang atau sebesar $33,33 \%$ dan 6 orang atau sebesar 20\%. Hasil penelitian menunjukkan bahwa rata-rata petani jagung di Desa Poopo berusia 51 tahun, dengan kisaran umur 37 - 70 tahun. Hal ini menandakan bahwa sebagian besar petani jagung di Desa Poopo berada pada kategori yang secara fisik dan daya pikir yang masih kuat berproduktivitas.

\section{Tingkat Pendidikan}

Data tingkat pendidikan sampael petani jagung di Desa Poopo Kecamatan Passi Timur terangkum pada tabel 2.

Tabel 2. Tingkat Pendidikan Petani Jagung di Desa Poopo Kecamatan Passi Timur

\begin{tabular}{lccc}
\hline \multirow{2}{*}{ No } & Tingkat Pendidikan & Jumlah & $\begin{array}{c}\text { Persentase } \\
(\%)\end{array}$ \\
\cline { 3 - 4 } & & 17 & 56,66 \\
2. & $\begin{array}{c}\text { Sekolah Dasar (SD) } \\
\text { Sekolah Menengah } \\
\text { Pertama (SMP) }\end{array}$ & 2 & 6,67 \\
3. & $\begin{array}{c}\text { Sekolah Menengah Atas } \\
\text { (SMA) }\end{array}$ & 11 & 36,67 \\
\hline Total & & $\mathbf{3 0}$ & $\mathbf{1 0 0}$ \\
\hline
\end{tabular}

Sumber: Diolah dari data primer, 2020

Tabel 2 menunjukkan bahwa sebagian besar petani jagung di Desa Poopo Kecamatan Passi Timur berpendidikan rendah. Hal ini terlihat pada nilai persentase terbesar yakni sebanyak 17 orang atau $56,66 \%$ berpendidikan SD. Selebihnya sebanyak 11 orang atau $36,67 \%$ 
berpendidikan SMA dan sebanyak 2 orang atau sebesar $6,67 \%$ berpendidikan SMP.

\section{Status Kepemilikan}

Sebagian besar petani Jagung di Desa Poopo Kecamatan Passi Timur mengelola sendiri usahataninya, atau berstatus sebagai pemilik / milik sendiri. Hal ini terlihat dari hasil penelitian pada Lampiran 1 yang menunjukkan bahwa seluruh sampel petani atau sebesar $100 \%$ berstatus milik sendiri.

\section{Lama Berusahatani}

Lamanya pengusahaan usahatani akan membentuk petani menjadi lebih berpengalaman dan memiliki banyak pengetahuan terutama tentang usahatani yang dikelolanya. Berikut data lama berusahatani sampel petani jagung di Desa Poopo Kecamatan Passi Timur yang terangkum pada Tabel 3.

Tabel 3. Lama Berusahatani Petani Jagung di Desa Poopo Kecamatan Passi Timur

\begin{tabular}{ccc}
\hline Lama & \multicolumn{2}{c}{ Petani } \\
\cline { 2 - 3 } Berusahatani & Jumlah & Persentase (\%) \\
\hline$\leq 10$ & 7 & 23,33 \\
$11-19$ & 14 & 46,67 \\
$\geq 20$ & 9 & 30 \\
\hline Total & $\mathbf{3 0}$ & $\mathbf{1 0 0}$ \\
\hline Sumber : Diolah dari data primer, 2020
\end{tabular}

Tabel 3 menunjukkan sebagian besar petani jagung di Desa Poopo Kecamatan Passi Timur telah berusahatani selama 11 - 19 tahun yaitu sebanyak 14 orang atau $46,67 \%$. Selanjutnya sebanyak 9 orang atau $30 \%$ telah berusahatani dibawah diatas 20 tahun, sedangkan selebihnya yaitu sebanyak 7 orang atau sebesar $23,33 \%$ berusahatani selama kurang dari 11 tahun. Hal ini menunjukkan bahwa petani jagung di Desa Poopo Kecamatan Passi Timur cukup berpengalaman dalam mengolah usahataninya.

\section{Luas Lahan}

\section{Usahatani Jagung}

Salah satu faktor produksi yang sangat penting dalam kegiatan usahatani adalah lahan, karena digunakan sebagai media tanam untuk budidaya tanaman jagung. Data luas lahan usahatani Jagung di Desa Poopo Kecamatan Passi Timur dapat dilihat pada Tabel 4 berikut.

Tabel 4. Luas Lahan Usahatani Jagung di Desa Poopo Kecamatan Passi Timur

\begin{tabular}{ccc}
\hline \multirow{2}{*}{ Luas Lahan } & \multicolumn{2}{c}{ Petani } \\
\cline { 2 - 3 } & Jumlah & Persentase (\%) \\
\hline 0,5 & 12 & 40 \\
$1-2$ & 14 & 46,66 \\
$\geq 2$ & 4 & 13,34 \\
\hline Total & $\mathbf{3 0}$ & $\mathbf{1 0 0}$ \\
\hline \multicolumn{2}{l}{ Sumber : Diolah dari data primer, 2020}
\end{tabular}

Tabel 4 diketahui bahwa sebagian besar petani jagung di Desa Poopo Kecamatan Passi Timur menguasai lahan dengan luas antara 1 - 2 hektar yaitu sebanyak 14 orang atau $46,66 \%$. Diikuti oleh petani jagung dengan luas lahan dibawah 1 hektar yaitu sebanyak 12 orang atau sebesar $40 \%$. Selebihnya sebanyak 4 orang atau $13,34 \%$ menguasai luas lahan lebih besar dari 1 hektar.

\section{Jumlah Produksi dan Harga Jual Jagung}

Hasil penelitian menunjukkan bahwa rata-rata jumlah produksi jagung yang dihasilkan oleh petani jagung di Desa Poopo Kecamatan Passi Timur yaitu 1.363 kg/petani dan $1.278,13 \mathrm{~kg} / \mathrm{ha}$ (lampiran 2). Harga jual yang berlaku pada saat penelitian dilakukan yaitu $\mathrm{Rp} 4.000$ per kg. Berikut data jumlah produksi usahatani jagung di Desa Poopo Kecamatan Passi Timur yang terangkum pada Tabel 5.

Tabel 5. Jumlah Produksi Usahatani Jagung di Desa Poopo Kecamatan Passi Timur

\begin{tabular}{|c|c|c|c|}
\hline \multirow[b]{2}{*}{ No } & \multirow{2}{*}{$\begin{array}{c}\text { Jumlah } \\
\text { Produksi (kg) }\end{array}$} & \multicolumn{2}{|c|}{ Petani } \\
\hline & & Jumlah & $\begin{array}{c}\text { Persentase } \\
(\%)\end{array}$ \\
\hline 1. & $<1000$ & 8 & 26,67 \\
\hline 2. & $1000-2000$ & 19 & 63,33 \\
\hline \multirow{2}{*}{3.} & $>2000$ & 3 & 10 \\
\hline & Total & 30 & 100 \\
\hline
\end{tabular}

Tabel 5 diketahui bahwa sebagian besar petani jagung di Desa Poopo Kecamatan Passi Timur yakni sebanyak 19 orang atau 63,33\% memproduksi jagung sebanyak $1.000-2.000$ kg. Diikuti sebanyak 8 orang atau $26,67 \%$ 
memproduksi jagung kurang dari $1.000 \mathrm{~kg}$, sedangkan sisanya yakni sebanyak 3 orang atau $10 \%$ memproduksi jagung sebanyak $2.000 \mathrm{~kg}$ keatas.

\section{Penggunaan dan Biaya Sarana Produksi}

Dalam rangka meningkatkan hasil produksi jagung, petani senantiasa berupaya melakukan pemupukan dan pemberian obat. Jenis pupuk yang diberikan oleh sebagian besar petani jagung di Desa Poopo Kecamatan Passi Timur yaitu Urea dan Phonska. Jenis obat yang banyak digunakan yaitu Nokson, sedangkan benih yang dipakai yaitu jenis paket Bisi 18. Pada Tabel 6, menunjukkan bahwa rata-rata penggunaan pupuk pada usahatani jagung di Desa Poopo Kecamatan Passi Timur yaitu 77 kg/petani dan 71,96 kg/ha. Penggunaan benih 12,33 $\mathrm{kg} /$ petani dan $11,53 \mathrm{~kg} / \mathrm{ha}$.

Tabel 6. Rata-Rata Penggunaan Saprodi pada Usahatani Jagung di Desa Popo Kecamatan Passi Timur

\begin{tabular}{cccc}
\hline \multirow{2}{*}{ No } & Sarana Produksi & \multicolumn{2}{c}{ Rata-rata Penggunaan } \\
\cline { 3 - 4 } & & Per petani & Per hektar \\
\hline \multirow{2}{*}{1.} & Pupuk (kg) & 77 & 71,96 \\
2. & Benih (kg) & 12,33 & 11,53 \\
3. & Obat (liter) & 1,80 & 1,68 \\
\hline \multicolumn{2}{l}{ Sumber : Diolah dari data primer, 2020}
\end{tabular}

Biaya saprodi adalah total biaya yang digunakan untuk pembelian sarana produksi pupuk, benih, dan obat. Biaya saprodi diperoleh melalui hasil perkalian jumlah saprodi yang digunakan dengan harga jual saprodi yang berlaku. Harga jual pupuk yaitu

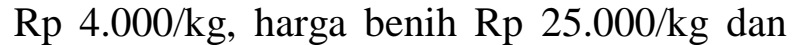
harga obat $\mathrm{Rp} 65.000$ /liter. Tabel 7 menunjukkan bahwa rata-rata biaya sarana produksi pada usahatani Jagung di Desa Poopo Kecamatan Passi Timur yaitu Rp 731.333,33/petani dan $\mathrm{Rp} 683.489,10$ /ha. Komposisi penyusun biaya saprodi per petani yaitu biaya pupuk Rp 306.000, benih Rp 308.333,33 dan biaya obat Rp 117.000, sedangkan per hektar biaya pupuk Rp 285.981,31, biaya benih $\mathrm{Rp} 288.166,99$ dan biaya obat Rp 109.345,79
Tabel 7. Rata-Rata Biaya Sarana Produksi Pada Usahatani Jagung di Desa Poopo Kecamatan Passi Timur

\begin{tabular}{llrr}
\hline \multirow{2}{*}{ No } & Sarana & \multicolumn{2}{c}{ Rata-rata Biaya $($ Rp) } \\
\cline { 3 - 4 } & Produksi & Per petani & Per hektar \\
\hline 1. & Pupuk & $306.000,00$ & $285.981,31$ \\
2. & Benih & $308.333,33$ & $288.166,99$ \\
3. & Obat & $117.000,00$ & $109.345,79$ \\
\hline \multicolumn{2}{r}{ Total } & $\mathbf{7 3 1 . 3 3 3 , 3 3}$ & $\mathbf{6 8 3 . 4 8 9 , 1 0}$ \\
\hline
\end{tabular}

\section{Penggunaan dan Biaya Tenaga Kerja}

Tenaga kerja yang digunakan oleh petani jagung di Desa Poopo Kecamatan Passi Timur terdiri atas tenaga kerja dalam keluarga dan luar keluarga, meliputi kegiatan penanaman, pemupukan, penyiangan, penyemprotan, dan panen. Pada Tabel 8, diperoleh bahwa rata-rata penggunaan tenaga kerja pada Usahatani Jagung di Desa Poopo Kecamatan Passi Timur per petani yaitu 22,77 HOK/petani dan 21,28 HOK/ha. Hasil penelitian menunjukkan penggunaan tenaga kerja yang paling banyak dibutuhkan dalam kegiatan usahatani jagung yaitu pada kegiatan penanaman dan kegiatan panen.

\begin{tabular}{lcc}
$\begin{array}{l}\text { Tabel 8. Rata-Rata Penggunaan Tenaga Kerja pada } \\
\text { Usahatani Jagung di Desa Poopo Kecamatan Passi Timur }\end{array}$ \\
\hline \multirow{2}{*}{ Kegiatan } & $\begin{array}{c}\text { Rata-rata Penggunaan Tenaga } \\
\text { Kerja (HOK) }\end{array}$ \\
\cline { 2 - 3 } & Per petani & Per hektar \\
\hline - Penanaman & 9,17 & 8,57 \\
- Pemupukan & 1,9 & 1,78 \\
- Penyemprotan & 1,2 & 1,12 \\
- Panen & 10,5 & 9,81 \\
\hline Total & $\mathbf{2 2 , 7 7}$ & $\mathbf{2 1 , 2 8}$
\end{tabular}

Sumber : Diolah dari data primer, 2020

Perhitungan biaya tenaga kerja didasarkan pada sistem pembayaran ongkos kerja yang berlaku di kecamatan Passi Timur, yaitu Rp 70.000/HOK. Rata-rata biaya tenaga kerja pada usahatani jagung di Desa Poopo Kecamatan Passi Timur dapat dilihat pada Tabel 9.

Tabel 9. Rata-Rata Biaya Tenaga Kerja pada Usahatani Jagung di Desa Poopo Kecamatan Passi Timur

\begin{tabular}{lcc}
\hline \multirow{2}{*}{ Kegiatan } & \multicolumn{2}{c}{ Rata-rata Biaya Tenaga Kerja (Rp) } \\
\cline { 2 - 3 } & Per petani & Per hektar \\
\hline - Penanaman & 641.667 & 599.688 \\
- Pemupukan & 133.000 & 124.299 \\
- Penyemprotan & 84.000 & 78.505 \\
- Panen & 735.000 & 686.916 \\
\hline Total & $\mathbf{1 . 5 9 3 . 6 6 7}$ & $\mathbf{1 . 4 8 9 . 4 0 8}$ \\
\hline
\end{tabular}

Sumber : Diolah dari data primer, 2020 
Tabel 9 menunjukkan bahwa rata-rata biaya tenaga kerja pada usahatani jagung di Desa Poopo Kecamatan Passi Timur yaitu sejumlah Rp 1.593.667/petani dan Rp 1.489.408/ha. Rata-rata biaya tenaga kerja terbesar yaitu pada kegiatan panen dan penanaman.

\section{Peralatan dan Biaya Penyusutan}

Peralatan merupakan sarana penunjang kegiatan usahatani yang harus dimiliki oleh petani. Peralatan yang banyak digunakan oleh petani jagung di Desa Poopo Kecamatan Passi Timur antara lain cangkul, mesin paras, dan tengki. Lamanya penggunaan (umur ekonomis) peralatan tersebut, rata-rata berjangka waktu 5 (lima) tahun. Rata-rata jumlah peralatan pada usahatani jagung di Desa Poopo Kecamatan Passi Timur dapat dilihat pada Tabel 10.

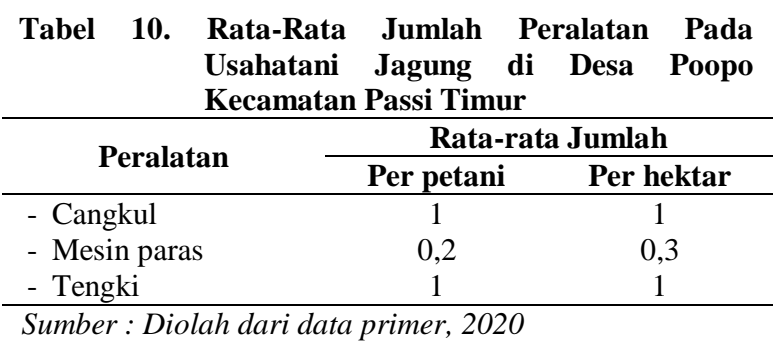

Tabel 10 diketahui bahwa semua petani jagung memiliki peralatan cangkul dan tengki yakni rata-rata memiliki 1 unit, namun hanya sebagian kecil petani agung yang memiliki alat mesin paras.

Biaya penyusutan peralatan yang digunakan oleh petani sangat berpengaruh terhadap biaya tetap yang akan dikeluarkan oleh petani. Penghitungan nilai penyusutan yaitu dengan menggunakan metode garis lurus antara nilai beli dan umur teknis peralatan tersebut. Nilai penyusutan untuk peralatan usahatani jagung dapat dilihat pada Tabel 11 berikut.

Tabel 11. Rata-Rata Biaya Penyusutan Peralatan pada Usahatani Jagung di Desa Poopo Kecamatan Passi Timur

\begin{tabular}{lcc}
\hline \multirow{2}{*}{ Peralatan } & \multicolumn{2}{c}{ Rata-rata Biaya Penyusutan } \\
\cline { 2 - 3 } & Per petani & Per hektar \\
\hline - Cangkul & 3.103 & 2.900 \\
- Mesin paras & 11.978 & 11.194 \\
- Tengki & 22.389 & 20.924 \\
\hline Total & $\mathbf{3 7 . 4 6 9}$ & $\mathbf{3 5 . 0 1 8}$ \\
\hline Sumber : Diolah dari data primer, 2020
\end{tabular}

Tabel 11 menunjukkan bahwa rata-rata total biaya penyusutan pada usahatani jagung di Desa Poopo Kecamatan Passi Timur yaitu sebesar Rp 37.469 /petani dan Rp 35.018 /ha. Biaya penyusutan terbesar yaitu terdapat pada alat tengki.

\section{Analisis Pendapatan Usahatani Jagung}

\section{Biaya Produksi Usahatani Jagung}

Biaya produksi dibedakan menjadi dua, yaitu biaya tetap dan biaya variabel. Biaya tetap adalah biaya yang konstan atau tetap tidak dipengaruhi oleh besar kecilnya produksi, seperti biaya penyusutan alat dan pajak. Biaya variabel adalah biaya yang besar kecilnya berhubungan dengan besar kecilnya produksi, seperti biaya saprodi, upah TK dan transportasi. Biaya produksi yang dikeluarkan dalam satu kali panen usahatani jagung di Desa Poopo Kecamatan Passi Timur dapat dilihat pada Tabel 12.

Tabel 12. Biaya Produksi Usahatani Jagung di Desa Poopo Kecamatan Passi Timur

\begin{tabular}{lcc}
\hline \multirow{2}{*}{ Biaya Produksi } & \multicolumn{2}{c}{ Rata-rata (Rp) } \\
\cline { 2 - 3 } & Per petani & Per hektar \\
\hline 1. Biaya Tetap & $137.469,44$ & $128.476,12$ \\
- Pajak & $100.000,00$ & $93.457,94$ \\
- Penyusutan & $37.469,44$ & $35.018,17$ \\
2. Biaya Variabel & $2.529 .500,00$ & $2.364 .018,69$ \\
- Tenaga kerja & $1.593 .666,67$ & $1.489 .408,10$ \\
- Sarana produksi & $731.333,33$ & $683.489,10$ \\
- Transportasi & $204.500,00$ & $191.121,00$ \\
\hline Total & $\mathbf{2 . 6 6 6 . 9 6 9 , 4 4}$ & $\mathbf{2 . 4 9 2 . 4 9 4 , 8 1}$ \\
\hline Sumber $:$ Diolah dari data primer, 2020 &
\end{tabular}

Tabel 12 diperoleh bahwa rata-rata biaya produksi pada usahatani jagung di Desa Poopo Kecamatan Passi Timur per petani yaitu sebesar $\mathrm{Rp} 2.666 .969,44$, yang terdiri atas biaya tetap $\mathrm{Rp} 137.469,44$ dan biaya variabel $\mathrm{Rp}$ 2.529.500, dan per hektar yaitu sebesar $\mathrm{Rp}$ $2.492 .494,81$, terdiri atas biaya tetap $\mathrm{Rp}$ 128.476,12 dan Rp 2.364.018,69.

\section{Penerimaan Usahatani Jagung}

Penerimaan usahatani jagung adalah jumlah total produksi jagung yang dijual berdasarkan pada harga yang berlaku di pasar. Hasil penelitian menunjukkan bahwa rata-rata jumlah produksi jagung yang dihasilkan oleh pada usahatani jagung di Desa Poopo Kecamatan Passi Timur yaitu $1.363 \mathrm{~kg} /$ petani dan $1.278,13$ /ha 
(lampiran 2), dan harga jual yang berlaku pada saat penelitian dilakukan yaitu Rp 4.000 per kg, sehingga rata-rata penerimaan usahatani jagung di Desa Poopo Kecamatan Passi Timur adalah sebesar Rp 5.453.333,33/petani dan Rp $5.096 .573,21 /$ ha.

\section{Pendapatan Usahatani Jagung}

Nilai pendapatan usahatani jagung diperoleh dari selisih penerimaan dan biaya usahatani. Pendapatan rata-rata petani jagung di Desa Poopo Kecamatan Passi Timur yaitu sebesar Rp 2.786.363,89/petani dan Rp 2.604.078,40/ha. Pendapatan rata-rata usahatani jagung dapat dilihat pada Tabel 13 .

Tabel 13. Pendapatan Rata-Rata Usahatani Jagung di Desa Poopo Kecamatan Passi Timur

\begin{tabular}{lcc}
\hline $\begin{array}{c}\text { Pendapatan Rata-rata } \\
(\mathbf{R p})\end{array}$ & \multicolumn{2}{c}{ Petani } \\
\cline { 2 - 3 } & Jumlah & $\begin{array}{c}\text { Persentase } \\
(\mathbf{\%})\end{array}$ \\
\hline$<2.000 .000$ & 8 & 26,67 \\
$2.000 .000-5.000 .000$ & 14 & 46,66 \\
$>5.000 .000$ & 8 & 26,67 \\
\hline Total & $\mathbf{3 0}$ & $\mathbf{1 0 0}$ \\
\hline Sumber : Diolah dari data primer, 2020 &
\end{tabular}

Tabel 13 menunjukkan bahwa sebagian besar petani jagung di Desa Poopo Kecamatan Passi Timur, yakni 14 petani atau $46,67 \%$ berpendapatan rata-rata antara $\mathrm{Rp}$ 2.000.000 - Rp 5.000.000. Sebanyak 8 petani atau $26,67 \%$ menghasilkan pendapatan ratarata dibawah $\mathrm{Rp} 2.000 .000$, dan diatas $\mathrm{Rp}$ 5.000.000.

\section{Nilai R/C Rasio Usahatani Jagung}

Analisis R/C rasio adalah perbandingan antara penerimaan dan biaya. Hasil perhitungan analisis $\mathrm{R} / \mathrm{C}$ rasio sebagai berikut:

$$
\begin{aligned}
& \mathrm{a}=\mathrm{R} / \mathrm{C} \\
& =5.453 .333,33 / 2.666 .969,44 \\
& =2,04
\end{aligned}
$$

Nilai R/C 2,04, memiliki arti bahwa setiap pengeluaran yang dilakukan oleh petani jagung sebesar $\mathrm{Rp} \mathrm{1,-}$ akan menghasilkan penerimaan sebesar Rp. 2,04. Nilai R/C rasio lebih dari satu menunjukkan bahwa usahatani tersebut mampu memberikan keuntungan 2,04 kali dari biaya yang dikeluarkan. Dengan demikian dapat disimpulkan bahwa usahatani jagung di Desa Poopo Kecamatan Passi Timur sangat layak, karena relatif menguntungkan.

\section{KESIMPULAN DAN SARAN}

\section{Kesimpulan}

Pendapatan rata-rata petani jagung di Desa Poopo Kecamatan Passi Timur yaitu sebesar Rp 2.786.363,89 /petani dan Rp 2.604.078,40 /ha, dengan nilai $\mathrm{R} / \mathrm{C}$ yang dihasilkan per petani yaitu 1,06 . Nilai $\mathrm{R} / \mathrm{C}$ rasio yang dihasilkan lebih dari satu menunjukkan bahwa usahatani jagung di Desa Poopo Kecamatan Passi Timur Kabupaten Bolaang Mongondow layak diusahakan.

\section{Saran}

1. Usahatani jagung di Desa Poopo Kecamatan Passi Timur Kabupaten Bolaang Mongondow layak untuk diusahakan, oleh karena itu pemerintah dan petani harus bekerja sama terutama dalam mencari solusi bagi hambatan-hambatan yang ada, agar usahatani jagung tidak hanya diusahakan namun juga lebih dikembangkan.

2. Diperlukan penelitian lebih lanjut terutama mengenai efisiensi penggunaan faktor-faktor produksi jagung, agar diketahui apakah pendapatan yang diperoleh tersebut berdasarkan penggunaan faktor-faktor produksi yang tepat atau tidak.

\section{DAFTAR PUSTAKA}

Astuti, 2013. Analisis Pendapatan Usaha Tani Padi Sawah (Oriza Sarival) di Kecamatan Kaway Kabupaten Aceh Barat. Program Studi Agribisnis Fakultas Pertanian Universias Teuku Umar Meulaboh Aceh Barat.

Mukhlis, 2007. Analisis Penawaran Jagung untuk Pakan Ayam Ras di Kabupaten Lima Puluh Kota. Jurnal Penelitian Lumbung. Politeknik Pertanian Negeri Payakumbuh. 10 (2): 1-10. 
Noor, H., Faizal. 2007. Ekonomi Majerial. Jakarta: Raja Grafindo Persada.

Rukmana, 2008. Usaha Tani Jagung. Kanisius, Yogyakarta

Shinta, A., 2005. Ilmu Usahatani. Diktat Kuliah Jurusan Sosial Ekonomi Pertanian Fakultas Pertanian Universitas Brawijaya. Malang.

Soekartawi. 2002. Analisis Usahatani. UI Press, Jakarta 